J. Perinat. Med. 10 (1982) 161

\section{Effects of orally administered Clenbuterol on oxy tocin-induced uterine activity}

\author{
H. C. S. Wallenburg, J. H. N. Schram \\ Department of Obstetrics \& Gynecology \\ Erasmus University Medical School, Rotterdam, The Netherlands
}

Clenbuterol is a sympathicomimetic agent with a predominant effect on beta $_{2}$-adrenergic receptors [6]. In addition to its bronchospasmolytic effect it inhibits uterine contractions and has been recommended for treatment of premature labor [6]. The results of pharmacokinetic studies in nonpregnant animals $[4,7]$ and in nonpregnant human individuals [8] indicate rapid absorption of an oral dose of Clenbuterol by the gastro-intestinal tract, resulting in relatively high plasma levels of the unchanged compound. Elimination of orally administered isotope-labelled Clenbuterol was shown to follow a biphasic curve with a half-life of 3035 hours in the second, slow phase [8].

If these pharmacologic properties would also be valid in pregnant women with uterine contractions, oral administration of Clenbuterol would appear to be an attractive approach to the treatment of premature labor. Therefore, the present study was designed to measure the effects of single oral doses of Clenbuterol on uterine activity as well as on variables of maternal and fetal cardiovascular function.

The study was performed in term pregnant women with oxytocin-induced labor in order to obtain standardized uterine activity and to allow continuous measurement of intrauterine pressure and fetal heart rate.

\section{Patients and methods}

Informed consent for this study was obtained from ten nulliparous and fifteen parous women who received obstetric care at the AZR-Dijkzigt Clinic and had opted for elective induction of labor. The general and obstetric history of all women was negative with regard to major diseases and complications of pregnancy, and the course of the present pregnancy was uncomplicated with normal fetal growth as confirmed by ultrasonic measurement of the fetal biparietal diameter. All women presented between 39 and 42 weeks of amenorrhea with a single fetus in the cephalic position and a ripe cervix according to the BURNHILL-score [1].

\subsection{Induction of labor and monitoring}

Labor was induced by means of low amniotomy followed by intravenous infusion of incremental doses of oxytocin. No other drugs were used except for the occasional administration of pethidine- $\mathrm{HCl}$ for pain relief. An open-tip catheter filled with sterile destilled water was introduced transcervically into the amniotic cavity for continuous measurement of uterine activity and a spiral electrode (Corometrics B-2462) was attached to the fetal scalp for continuous recording of the fetal EKG and cardiotachogram. A maternal tachogram was derived from the maternal EKG and maternal blood pressure was measured between uterine contractions at 10 minute intervals with an automatic ultrasound device (Arteriosonde, Roche). All signals were written on a multichannel polygraph and recorded on magnetic tape. 


\subsection{Experimental protocol}

Starting with $1.8 \mathrm{mU}$ per minute the dose of oxytocin was increased stepwise until stable uterine activity of three contractions per 10 minutes with an intensity of approximately $50 \mathrm{~mm}$ of $\mathrm{Hg}$ at a constant oxytocin infusion rate was obtained during a control period of at least 30 minutes. Then a vaginal examination was done to assess the degree of cervical dilatation and engagement of the fetal head and Clenbuterol* was given in a single oral dose of 40,80 or $160 \mu \mathrm{g}$. The effects on uterine activity and on maternal and fetal cardiovascular variables were measured during an experimental period of at least 130 minutes following the administration of Clenbuterol, except in cases in which delivery occurred within that period of time. The oxytocin infusion rate was kept constant during the experimental period. The data was analyzed by means of an appropriately programmed computer (PDP-11/70). Uterine activity was calculated by multiplying the maximum height $(\mathrm{mm} \mathrm{Hg})$ of the pressure curve as measured from a level of $20 \mathrm{~mm}$ of $\mathrm{Hg}$ times the interval (min) between the two points of intersection of the $20 \mathrm{~mm} \mathrm{Hg}$ level with the pressure curve [5]. The advantage of using a $20 \mathrm{~mm} \mathrm{Hg}$ level as a reference line is that it allows sharp definition of the "onset" and the "end" of a uterine contrac- tion. The products of intrauterine pressure and time thus calculated for :each contraction during a period of time of 10 minutes were added and expressed as uterine activity units (UAUs). Women who showed a decrease in uterine activity units of $10 \%$ or more during two consecutive periods of 10 minutes in the experimental period as compared with the mean uterine activity in the control period were labelled "responders".

Appropriate non-parametric tests were applied where necessary for statistical analysis and $p<0.05$ was chosen as the level of significance.

\section{Results}

Relevant data of the women involved in the study is summarized in Table $\mathrm{I}$. There were no differences at the end of the control period between patients receiving 40,80 or $160 \mu \mathrm{g}$ of Clenbuterol with regard to age, weight, duration of pregnancy, cervical dilatation and engagement of the fetal head, and uterine activity.

\subsection{Effect on uterine activity}

In 10 out of the 25 women uterine activity decreased following an oral dose of Clenbuterol (Tab. I). In the remaining 15 women uterine

Tab. I. Relevant data of women receiving an oral dose of Clenbuterol during oxytocin-induced labor.

\begin{tabular}{|c|c|c|c|c|c|c|c|c|}
\hline & $\begin{array}{l}\text { Dose } \\
\text { of } \\
\text { Clen- } \\
\text { bute- } \\
\text { rol } \\
(\mu \mathrm{g})\end{array}$ & $\begin{array}{l}\text { Numb } \\
\text { of pat } \\
\text { Nulli- } \\
\text { par- } \\
\text { ous }\end{array}$ & $\begin{array}{l}\text { ients } \\
\text { ient }\end{array}$ & $\begin{array}{l}\text { Age } \\
(\mathrm{yrs})^{1}\end{array}$ & $\begin{array}{l}\text { Weight } \\
(\mathrm{kg})^{1}\end{array}$ & $\begin{array}{l}\text { Amenorrhea }{ }^{1} \\
\text { (weeks) }\end{array}$ & $\begin{array}{l}\text { Cervical } \\
\text { dilatation } \\
\text { at end of } \\
\text { control } \\
\text { period } \\
\text { (cm) }\end{array}$ & $\begin{array}{l}\text { Uterine } \\
\text { activity in } \\
\text { control } \\
\text { period } \\
(\text { UAU) }\end{array}$ \\
\hline $\begin{array}{l}\text { Responders } \\
\text { Non- } \\
\text { responders }\end{array}$ & $\begin{array}{l}40 \\
40\end{array}$ & $\begin{array}{l}4 \\
1\end{array}$ & $\begin{array}{l}0 \\
4\end{array}$ & $\begin{array}{ll}26.5 & (23-31) \\
25.8 & (22-30)\end{array}$ & $\begin{array}{ll}86 & (75-118) \\
81 & (76-87)\end{array}$ & $\begin{array}{l}40(39-42) \\
39(38-40)\end{array}$ & $\begin{array}{ll}2 & (1-3) \\
3 & (2-4)\end{array}$ & $\begin{array}{r}111.7 \pm 8.6 \\
89.8 \pm 18.6\end{array}$ \\
\hline $\begin{array}{l}\text { Responders } \\
\text { Non- } \\
\text { responders }\end{array}$ & $\begin{array}{l}80 \\
80\end{array}$ & $\begin{array}{l}1 \\
3\end{array}$ & $\begin{array}{l}2 \\
3\end{array}$ & $\begin{array}{ll}27.3 & (22-30) \\
27.5 & (20-35)\end{array}$ & $\begin{array}{l}86(69-97) \\
69(65-78)\end{array}$ & $\begin{array}{l}39(39-40) \\
40(39-41)\end{array}$ & $\begin{array}{ll}2 & (2-3) \\
2 & (2-3)\end{array}$ & $\begin{array}{l}96.8 \pm 18.5 \\
80.0 \pm 19.7\end{array}$ \\
\hline $\begin{array}{l}\text { Responders } \\
\text { Non- } \\
\text { responders }\end{array}$ & $\begin{array}{l}160 \\
160\end{array}$ & $\begin{array}{l}1 \\
0\end{array}$ & $\begin{array}{l}2 \\
4\end{array}$ & $\begin{array}{ll}25.3 & (23-27) \\
24.5 & (21-27)\end{array}$ & $\begin{array}{l}78(65-103) \\
79(60-108)\end{array}$ & $\begin{array}{l}40(39-41) \\
40(39-42)\end{array}$ & $\begin{array}{ll}3 & (2-4) \\
3 & (2-4)\end{array}$ & $\begin{array}{l}89.3 \pm 10.5 \\
94.0 \pm 26.8\end{array}$ \\
\hline
\end{tabular}

1 Mean (range) ${ }^{2}$ Mean \pm S.D.

* Gift from Boehringer-Ingelheim, Haarlem, the Netherlands. 
activity remained equal or increased during the experimental period. A decrease in uterine activity was observed in six out of ten nulliparous women, and in four out of 15 parous patients; the difference is not significant (FISHER test). The fall in uterine activity following $40 \mu \mathrm{g}$ of Clenbuterol was significantly less than that following an 80 or a $160 \mu \mathrm{g}$ dose (Fig. 1), but no difference was apparent between the effect of an $80 \mathrm{mg}$ and a $160 \mathrm{mg}$ dose.

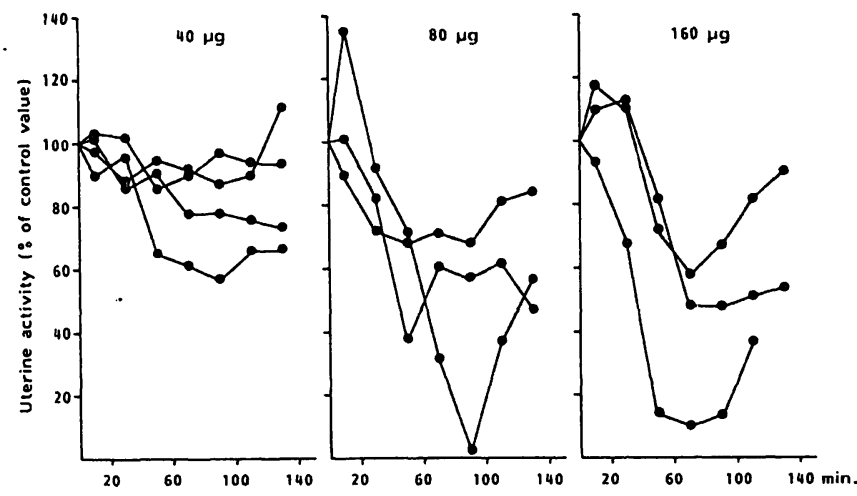

Fig. 1. Uterine activity (UAUs) expressed as a percentage of the control value in 10 women responding to an oral dose of 40,80 or $160 \mu \mathrm{g}$ of Clenbuterol.

The decrease in uterine activity as measured in UAUs appeared to be due to a simultaneous decrease in frequency and in intensity of the contractions. The labor-inhibiting effect of Clenbuterol became apparent in all responders $30-40 \mathrm{~min}$ utes after oral administration, the maximum fall in uterine activity occurred after 60-80 minutes. In the $40 \mu \mathrm{g}$ group uterine activity in 2 of the 4 responders returned to the control level within two hours. In the remaining responders uterine activity was still significantly decreased two hours after administration of Clenbuterol.

The mean duration of the first stage of labor following oral administration of Clenbuterol was 501 (range 140-1800) minutes in nulliparous responders, which is significantly longer than the 130 (range 110-400) minutes observed in nulliparous non-responders. In the parous responders the first stage of labor following Clenbuterol had a mean duration of 280 (range 155-495) minutes, which is significantly longer than that in the parous non-responders (mean $97 \mathrm{~min}$, range 43$270 \mathrm{~min}$ ). Three hours following an $80 \mu \mathrm{g}$ dose in one responder and $160 \mu \mathrm{g}$ in two responders uterine activity was still $50 \%$ or less of that in the control period. In these cases, oral administration of $40 \mathrm{mg}$ of propranolol resulted in the return of adequate uterine contractions.

\subsection{Maternal and fetal cardiovascular effects}

In the groups receiving 40 or $80 \mu \mathrm{g}$ of Clenbuterol no significant trend in maternal blood pressure or heart rate was observed during the experimental period.

No differences were apparent with regard to these variables between responders and non-responders. In the three women who responded to $160 \mu \mathrm{g}$ of Clenbuterol a marked increase in heart rate was observed, which started between 40 and $60 \mathrm{~min}$ utes after receiving Clenbuterol. In one patient the heart rate increased to 145 beats per minute with serious palpitations, whereas systolic and diastolic blood pressure remained stable. This responder showed the greatest fall in uterine activity observed in this group. The rise in heart rate was absent in the non-responders in this group (Fig. 2). Systolic blood pressure showed a slight increase and diastolic blood pressure fell at about $60 \mathrm{~min}$ utes following an oral dose of $160 \mu \mathrm{g}$ of Clenbuterol in responders, to an average of $80 \%$ of its baseline value.

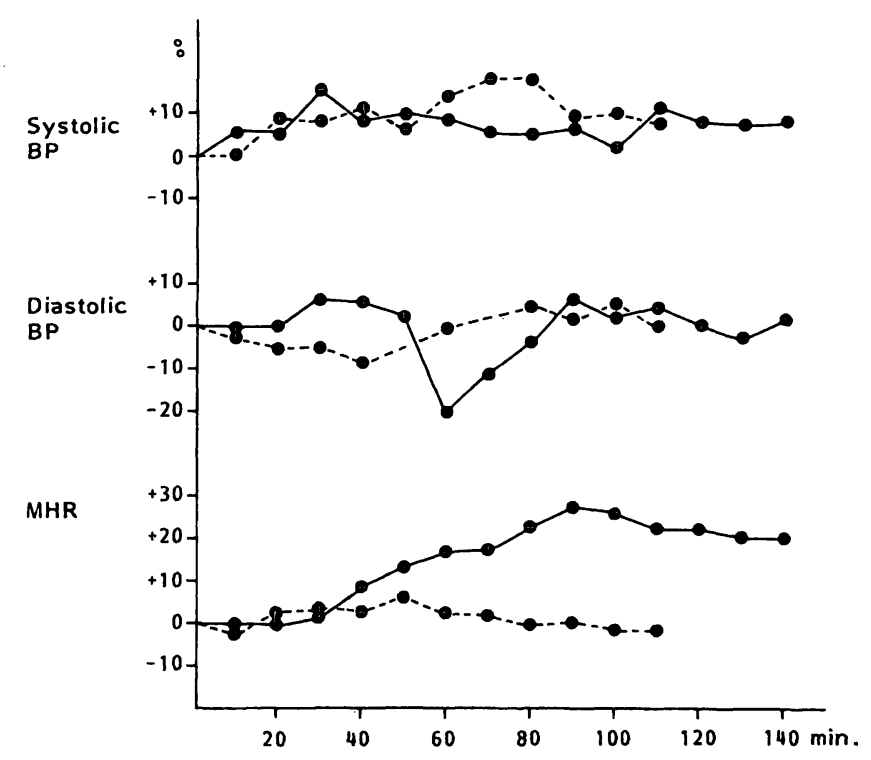

Fig. 2. Mean changes in maternal blood pressure (BP) and heart rate (MHR), expressed as percentages of control values, in women receiving an oral dose of $160 \mu \mathrm{g}$ of Clenbuterol. $\longrightarrow$ responders $(n=3)$; $\bullet-\bullet$ non-responders $(n=4)$. 
Fetal heart rate patterns remained unchanged in all cases. All infants were born alive and in good condition.

\section{Discussion}

The effect of an oral dose of Clenbuterol on uterine activity in parturient women in the begining of the first stage of labor appears to be variable: in $60 \%$ of our patients no effect at all was seen, whereas uterine activity was clearly inhibited in the remaining $40 \%$.

In the responders the decrease in uterine activity was less marked with a $40 \mu \mathrm{g}$ dose than with 80 or $160 \mu \mathrm{g}$ of Clenbuterol. Since no difference was apparent between the degree of myometrial inhibi: tion obtained with $80 \mu \mathrm{g}$ and that following $160 \mu \mathrm{g}, 80 \mu \mathrm{g}$ of Clenbuterol appears to be an optimal oral dose.

All responders show a similar pattern of inhibition of myometrial activity: labor activity begins to decrease 30-40 minutes after oral administration of Clenbuterol, and a maximum fall in uterine activity is observed after 60-80 minutes, followed by a gradual increase in frequency and intensity of uterine contractions. The effect of Clenbuterol appears to be long-lasting: uterine activity was still significantly reduced two hours after oral administration in all responders except in two patients who received a $40 \mu \mathrm{g}$ dose.

Our finding that more than half the number of women studied did not respond at all might be attributed to absent or inadequate intestinal absorption of the agent due to delayed gastric emptying in these cases. Clenbuterol is absorbed by the intestinal tract and it is known that gastric emptying often stops completely during labor [2]. Because a plasma assay of Clenbuterol was not available we were unable to adduce direct evidence to support or refute this hypothesis.

\section{Summary}

The effects of a single oral dose of the beta-sympathicomimetic agent Clenbuterol on uterine activity and maternal and fetal cardiovascular variables were experimentally investigated in 25 women in the first stage of oxytocininduced labor. Intra-amniotic pressure, and fetal and
The absence of significant differences in cervical dilatation, engagement of the presenting part, and baseline uterine activity at the time of administration of Clenbuterol between responders and nonresponders makes it unlikely that the variability of the response to Clenbuterol could be due to differences in the degree of labor.

Effects of Clenbuterol on maternal blood pressure and heart rate were apparent in all responders who received $160 \mu \mathrm{g}$ of Clenbuterol, but were absent in the non-responders, which lends indirect support to the hypothesis of poor absorption in these cases. Maternal tachycardia was observed to start earlier than the fall in diastolic blood pressure, and it was still present when diastolic blood pressure had returned to its control value. This suggests a direct positive chronotropic effect of Clenbuterol on the maternal heart, but the limited number of observations precludes firm conclusions in this respect.

Although Clenbuterol has been shown to be transferred across the placenta in animal experiments [4] we observed no effect on fetal heart rate, even not in women who responded to an oral dose of $160 \mu \mathrm{g}$.

In conclusion, an oral dose of $80 \mu \mathrm{g}$ of Clenbuterol appears to inhibit uterine activity effectively and with virtually no side effects during a period of time of more than two hours, provided that it is absorbed from the intestinal tract. However, intestinal absorption is known to be variable during labor due to the delay in gastric emptying. For this reason and also because of the relatively delayed onset of action, oral administration of Clenbuterol cannot be recommended for acute treatment of premature labor. However, it could be an attractive approach to maintenance of therapy once uterine contractions have been effectively inhibited by means of an intravenously administered sympathicomimetic agent, or to prevention of threatened premature labor.

maternal heart rate were continuously recorded, and maternal blood pressure was measured with an ultrasound device at 10 minute intervals. Myometrial contractility was expressed in uterine activity units (UAUs). After stable uterine activity of between 80 and 110 UAUs was 
obtained, an oral dose of 40,80 , or $160 \mu \mathrm{g}$ of Clenbuterol was given. In 10 women uterine contractions decreased following a single oral dose of Clenbuterol (responders), whereas in the remaining 15 women no effect on myometrial activity was observed (non-responders). In responders the fall in uterine activity following a $40 \mu \mathrm{g}$ dose was significantly less than that following an 80 or $160 \mu \mathrm{g}$ dose, but the difference between 80 and $160 \mu \mathrm{g}$ was not significant. In all responders the labor-inhibiting effect of Clenbuterol became apparent 30-40 minutes following oral administration, and the maximum decrease in uterine activity occurred after 60-80 minutes. Except in women who received $40 \mu \mathrm{g}$, the effect lasted at least 2 hours in all responders. An increase in maternal heart rate together with a rise in systolic blood pressure and a slight fall of the diastolic pressure were observed in responders who received $160 \mu \mathrm{g}$ of Clenbuterol but were absent in the other responders. Effects on fetal heart rate were never demonstrated. The absence of a response even to a high dose of Clenbuterol in 15 out of 25 women in early labor might be attributed to absent or inadequate intestinal absorption of the agent due to delayed gastric emptying which is known to occur during labor. On the basis of these findings we conclude that oral administration of Clenbuterol cannot be recommended for acute treatment of premature labor but could be an attractive approach to maintenance of therapy once uterine contractions have been effectively inhibited by means of an intravenously administered sympathicomimetic agent, or to prevention of threatened premature labor.

Keywords: Beta-sympathicomimetic drugs, clenbuterol, inhibition of labor, uterine relaxation.

\section{Zusammenfassung}

Die Beeinflussung der oxytocininduzierten Uteruskontraktionen durch orale Clenbuterolgabe

In unserer Untersuchung sollte der Einfluß einer Einzeldosis des Betasympathomimetikums Clenbuterol auf die Uterustätigkeit sowie die mütterlichen und fetalen cardiovaskulären Parameter bei oxytocin-induzierten Wehen geprüft werden. Das Untersuchungskollektiv bestand aus 25 Frauen in der Eröffnungsphase. Der intraamniale Druck sowie die maternale und fetale Herzfrequenz wurden kontinuierlich aufgezeichnet; die Messung des mütterlichen Blutdrucks erfolgte über Ultraschallableitung in Abständen von 10 Minuten. Maß für die Kontraktibilität des Myometriums waren ,uterine Aktivitätseinheiten (UAU's)'. Wenn die Uterustätigkeit eine Stärke von 80-110 UAU's erreicht hatte, verabreichten wir oral 40 , 80 oder $160 \mu \mathrm{g}$ Clenbuterol. Bei 10 Frauen erfolgte daraufhin ein Abfall der Uterusaktivität, während bei den restlichen 15 Frauen kein Effekt zu beobachten war. Die Abnahme nach $40 \mu \mathrm{g}$ war signifikant geringer als nach $80 \mu \mathrm{g}$ und $160 \mu \mathrm{g}$. Zwischen $80 \mu \mathrm{g}$ und $160 \mu \mathrm{g}$ ließ sich aber kein statistisch signifikanter Unterschied nachweisen. Der wehenhemmende Effekt setzte schon nach 30 bis 40 Minuten ein und erreichte sein Maximum nach 60 bis 80 Minuten. Mit Ausnahme der Frauen, die $40 \mu \mathrm{g}$ erhalten hatten, hielten die Effekte über 2 Stunden an. Ein Anstieg der mütterlichen Herzfrequenz zusammen mit einem erhöhten systolischen Druck und einem leicht erniedrigten diastolischen Wert fand sich nur bei den Frauen, die die höchste Dosierung von $160 \mu \mathrm{g}$ Clenbuterol erhalten hatten. Die fetale Herzfrequenz wurde überhaupt nicht beeinflußt. Daß 15 Frauen selbst auf hohe Dosen gar nicht ansprachen, führen wir auf eine fehlende oder inadäquate intestinale Resorption zurück; es ist bekannt daß während der Geburt die Magenentleerung verzögert ist. Aus unseren Ergebnissen folgern wir, daß die orale Gabe von Clenbuterol als Therapie bei der Frühgeburt nicht empfohlen werden kann. Sinnvoll erscheint es aber, Clenbuterol als Erhaltungsdosis zu verabreichen, wenn die Uteruskontraktionen durch i.v. verabreichte Sympathomimetika effektiv gehemmt werden konnten oder in der Prävention bei drohender Frühgeburt einzusetzen.

Schlüsselwörter: Betasympathomimetika, Clenbuterol, Relaxierung des Uterus, Wehenhemmung.

\section{Résumé}

Effets de l'administration orale de Clenbutérol sur l'activité uterine induite par l'oxy tocine

Les effets d'une prise orale unique de Clenbutérol, médicament bétamimétique sur l'activité utérine et sur les paramètres cardio-vasculaires de la mère et du foetus, ont été explorés chez 25 femmes au cours de la première partie du travail déclenché par l'ocytocine. La pression intra-amniotique et le rythme cardiaque du foetus et de la mère ont été enregistrés de façon con tinuẹ; la pression artérielle maternelle a été mesurée toutes les 10 minutes à l'aide d'un dispositif ultra-sonore. L'activité contractile du myomètre a été exprimée en unités d'activité utérine (UAU). Lorsque une activité utérine stable comprise entre 80 et 110 UAU est obtenue, une prise orale de 40,80 ou $160 \mu \mathrm{g}$ de Clenbutérol est donnée. Chez 10 femmes les contractions utérines ont diminué à la suite d'une prise orale unique de Clenbutérol (répondeurs), tandis que chez les 15 femmes restantes, aucun effet sur l'activité myométriale n'a été noté (non-répondeurs). Dans le groupe des répondeurs, la chute de l'activité utérine à la suite d'une dose de $40 \mu \mathrm{g}$ est de façon significative moindre que celle suivant une dose de 80 ou de $160 \mu \mathrm{g}$, mais la différence entre 80 et $160 \mu \mathrm{g}$ n'est pas significative. Chez toutes les répondeurs l'effet d'inhibition sur le travail du Clenbutérol se manifeste 30 à 40 minutes après la prise orale, et la diminution maximale de l'activité utérine se produit au bout de 60 à 80 minutes. A l'exception des femmes ayant reçu $40 \mu \mathrm{g}$, l'effet s'achève au bout d'au moins 2 heures dans le groupe répondeurs. Une augmentation du rythme cardiaque maternel associée à une élévation de la pression systolique et à une légère diminution de la diastolique ont été observées chez les femmes répondeurs ayant reçu $160 \mu \mathrm{g}$ de Clenbutérol, 
modifications non retrouvées chez les autres femmes du groupe. Il n'a jamais été démontré d'effets sur le rythme cardiaque foetal. L'absence de réponse même à une dose élevée de Clenbutérol chez 15 des 25 femmes en début de travail peut être attribuée à une absorption intestinale absente ou inapropriée de la drogue en rapport avec le retard de l'évacuation gastrique que l'on observe pendant le travail. Sur la base de ces données les auteurs conclu- ent que la prise orale de Clenbutérol ne peut être recommandée comme traitement d'urgence du travail prématuré mais peut être ứe voie intéressante pour poursuivre le traitement une fois que les contractions utérines ont été efficacement inhibées au moyen d'une perfusion intra-veineuse de bétamimétiques ou pour la prévention de la menace d'accouchement prématuré.

Mots-clés: Clenbutérol, inhibition du travail, médicaments bétamimétiques, relaxation utérine.

\section{Bibliography}

[1] BURNHILL, M. S., J. DANEZIS, J. COHEN: Uterine contractility during labor studied by intra-amniotic fluid pressure recordings. Part I. Effect of age, parity, duration of pregnancy, quality of the cervix, sedation, position, dose level, and amount of oxytocin on the course of labor. Amer. J. Obstet. Gynec. 83 (1962) 561

[2] Davison, J. S., M. C. DaVison, D. M. HAY: Gastric emptying time in late pregnancy and labour. J. Obstet. Gynaecol. Brit. Cwlth. 77 (1970) 37

[3] ENGELhaRDT, G.: Pharmakologisches Wirkungsprofil von NAB 365 (Clenbuterol), einem neuen Broncholytikum mit einer selektiven Wirkung auf die adrenergen $\beta_{2}$-Rezeptoren. Arzneim. Forsch. (Drug. Res.) 26 (1976) 1404

[4] KOPITAR, Z., A. ZIMMER: Pharmakokinetik und Metabolitenmuster von Clenbuterol bei der Ratte. Arzneim. Forsch. (Drug. Res.) 26 (1976) 1435
[5] WLADIMIROFF, J. W., T. K. A. B. ESKES, A. C. DROGENDIJK, PH. VAN ELTEREN: Evaluation of fetal heart rate in relation to the intrauterine $20 \mathrm{~mm}$ Hg level. Europ. J. Obstet. Gynecol. Reprod. Biol. 5 (1975) 263

[6] ZAHN, V., G. KRUMBACHNER: Clenbuterol-A long term uterine relaxant. J. Perinat. Med. 9 (1981) 96

[7] ZIMMER, A.: Pharmakokinetik und Metabolitenmuster von Clenbuterol beim Kaninchen und beim Hund. Arzneim. Forsch. (Drug Res.) 26 (1976) 1442

[8] ZIMMER, A.: Einmalapplikation, Mehrfachapplikation und Metabolitenmuster von Clenbuterol beim Menschen. Arzneim. Forsch. (Drug. Res.) 26 (1976) 1446

Received November 11, 1981. Accepted February 4, 1982

Prof. Dr. H. C. S. Wallenburg

Dept. Obstetrics \& Gynecology

AZR-Dijkzigt, Dr. Molewaterplein 40

3015 GD Rotterdam

The Netherlands 